\title{
Alexandre Dumas, Chroniques de la Régence
}

\section{Lise Sabourin}

\section{OpenEdition}

\section{Journals}

Édition électronique

URL : http://journals.openedition.org/studifrancesi/4419

DOI : 10.4000/studifrancesi.4419

ISSN : 2427-5856

Éditeur

Rosenberg \& Sellier

\section{Édition imprimée}

Date de publication : 1 septembre 2016

Pagination : 348

ISSN : 0039-2944

\section{Référence électronique}

Lise Sabourin, «Alexandre Dumas, Chroniques de la Régence », Studi Francesi [En ligne], 179 (LX | II) |

2016, mis en ligne le 01 septembre 2016, consulté le 18 septembre 2020. URL : http://

journals.openedition.org/studifrancesi/4419; DOI : https://doi.org/10.4000/studifrancesi.4419

Ce document a été généré automatiquement le 18 septembre 2020.

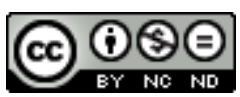

Studi Francesi è distribuita con Licenza Creative Commons Attribuzione - Non commerciale - Non opere derivate 4.0 Internazionale. 


\title{
Alexandre Dumas, Chroniques de la Régence
}

\author{
Lise Sabourin
}

\section{RÉFÉRENCE}

ALEXANDRE DUMAS, Chroniques de la Régence, édition préfacée et annotée par Claude Schopp, Paris, Librairie Vuibert, 2013, 348 pp.; rééd. Paris, Livre de Poche, 2015, «Classiques de Poche», 415 pp.

1 Dumas, on le sait, a voulu écrire non pas le drame dans l'histoire, mais celui de l'histoire: ses personnages sont les représentants des classes sociales, leurs antagonismes constituent la trame des événements dans la dynamique de l'aventure humaine. Il veut donner à comprendre le pathétique de l'humanité jetée dans l'histoire en instrument aveugle, mais dont la mémoire éclaire l'obscurité. C'est pourquoi les Chroniques de l'histoire de France écrites par Alexandre Dumas constituent un genre particulier, entre ses romans historiques, comme Le Chevalier d'Harmenthal en 1841-1842, et drames romantiques, tel Une fille du Régent en 1843-1845. Le volume édité et préfacé (pp. 3-21) par Claude Schopp, paru d'abord chez Vuibert en 2013 et réédité en classiques de Poche en 2015, est intéressant à ce titre, car ces Chroniques de la Régence offrent une vision anecdotique et comique, mais aussi illustrative du projet dumasien.

Couvrant les années 1715-1723, ces récits historiques s'inspirent des Mémoires de SaintSimon, réédités chez Delloye en 1840-1841, mais aussi de ceux de Duclos et de la princesse Palatine. Des témoins aussi différents que le grand écuyer du roi, M. de B[ois] Jourdain, et le redoutable intrigant que fut le puissant cardinal Dubois (dont les Mémoires avaient été édités par le bibliophile Jacob, Paul Lacroix, en 1829) fournissent à Dumas maints détails sur les aspects secrets de cette époque de transition. On lira donc avec plaisir cette édition qui rétablit le texte complet, tel que paru chez Cadot en 1849, sans publication préalable en journal, mais expurgé précédemment, depuis la réédition chez Michel Lévy en 1866, de ses détails les plus truculents. Les brefs paragraphes 
sautillants de Dumas retracent aussi bien les faits et gestes des princes et de leurs favorites, l'histoire de Cartouche ou les Noëls chantés en ces temps de licence après le long règne du roi Soleil, que le déroulement des funérailles de Louis XIV, avec tout le processus de captation du pouvoir vis-à-vis du duc du Maine que mena le Régent au profit d'un dauphin devenu roi à cinq ans, qu'il eut la grâce historique de mener à sa majorité au moment de quitter lui-même la scène du monde. 